\title{
Secondary metabolites and biodiversity of actinomycetes
}

\author{
Manal Selim Mohamed Selim, Sayeda Abdelrazek Abdelhamid* and Sahar Saleh Mohamed
}

\begin{abstract}
Background: The ability to produce microbial bioactive compounds makes actinobacteria one of the most explored microbes among prokaryotes. The secondary metabolites of actinobacteria are known for their role in various physiological, cellular, and biological processes.

Main body: Actinomycetes are widely distributed in natural ecosystem habitats such as soil, rhizosphere soil, actinmycorrhizal plants, hypersaline soil, limestone, freshwater, marine, sponges, volcanic cave — hot spot, desert, air, insects gut, earthworm castings, goat feces, and endophytic actinomycetes. The most important features of microbial bioactive compounds are that they have specific microbial producers: their diverse bioactivities and their unique chemical structures. Actinomycetes represent a source of biologically active secondary metabolites like antibiotics, biopesticide agents, plant growth hormones, antitumor compounds, antiviral agents, pharmacological compounds, pigments, enzymes, enzyme inhibitors, anti-inflammatory compounds, single-cell protein feed, and biosurfactant.

Short conclusions: Further highlight that compounds derived from actinobacteria can be applied in a wide range of industrial applications in biomedicines and the ecological habitat is under-explored and yet to be investigated for unknown, rare actinomycetes diversity.
\end{abstract}

Keywords: Actinomycetes, Biodiversity, Bioactive compound, Secondary metabolites

\section{Background}

The inquiry and discovery of novel microorganisms that produce new secondary metabolites can be required to stay critical in the race against new and rising diseases and antibiotic-resistant pathogens [1,2]. Actinomycetes are broadly distributed in natural and man-made conditions and assume a vital role in organic matter degradation. They are additionally notable as a rich source of bioactive secondary metabolites [1]. Secondary metabolites are known as organic compounds which are not specifically associated with the normal growth of an organism, improvement, or propagation of it. The diversity of Actinomycetes and their capacity to produce novel substances put this class in a noticeable position. They are in charge of the generation of about $50 \%$ of the

* Correspondence: sayeda.abdelrazek@yahoo.com

Microbial Biotechnology Department-Genetic Engineering Division, National Research Centre, Giza, Egypt

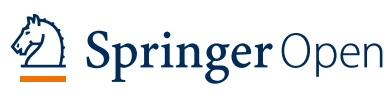

explored bioactive secondary metabolites, remarkably antibiotics, anticancer agents, anti-inflammatory agents, and enzymes [3, 4]. In light of the amazing reputation of actinomycetes, a lot of achievement has been centered on the fruitful isolation of new actinomycetes from various sources for medication screening programs in the past 50 years [5]. In the previous two decades, there has been a decrease in the revelation of new critical compounds from basic soil derived actinomycetes where they have produced huge numbers of previously described secondary metabolites $[6,7]$. Consequently, this prompts increment in the finding of new actinomycete taxa from abnormal environments which thus prompts make new age of drug specialists [8]. Actinomycetes produce a wide array of biologically active compounds such as antibiotics, enzymes, and enzyme inhibitors $[9,10]$. As of late, the rate of discovery of new compounds from actinomycetes of terrestrial sources has been diminished,

(c) The Author(s). 2021 Open Access This article is licensed under a Creative Commons Attribution 4.0 International License, which permits use, sharing, adaptation, distribution and reproduction in any medium or format, as long as you give appropriate credit to the original author(s) and the source, provide a link to the Creative Commons licence, and indicate if changes were made. The images or other third party material in this article are included in the article's Creative Commons licence, unless indicated otherwise in a credit line to the material. If material is not included in the article's Creative Commons licence and your intended use is not permitted by statutory regulation or exceeds the permitted use, you will need to obtain permission directly from the copyright holder. To view a copy of this licence, visit http://creativecommons.org/licenses/by/4.0/. 
while the rate of re-isolation of known compounds has likewise been expanded. Consequently, it is significant that new actinomycetes taxa from underexploited or from unexplored habitats consider as very important sources of new bioactive compounds [11, 12]. Hence, this article would concentrate on the recent scenario about diverse actinomycetes and their secondary metabolites.

\section{Distribution of actinomycetes}

Actinomycetes are capable of surviving in different habitats and are widely distributed in natural ecosystems. Actinomycetes are known as Gram +ve bacteria and characterized by the formation of aerial and substrate mycelium on solid media, also the presence of spores with different spore surfaces (Figs. 1 and 2), and high Guanine + Cytosine content of DNA [13]. Based on of morphological and chemical criteria, actinomycetes have been grouped into different genera (Table 1); Streptomyces is the most commonly isolated genera of the order Actinomycetales due to its great importance in medical science, ecology, and the biotechnology industry [11].

\section{Soil}

Actinomycetes population has been known as soil inhabitant. It was stated that only $10 \%$ of the actinomycetes has been isolated from nature [14]. So the researchers need to screen more actinomycetes that have not been discovered and capable of producing new antibiotics active against bacteria that are resistant to current antibiotics [15].

\section{Rhizosphere soil}

There are several groups of actinomycetes that are stable in bulk soil and in rhizosphere plants. Actinomycetes are very important for many plants, where rhizospheric streptomycetes can protect plant roots by inhibiting the growth of fungal pathogen a character based on their ability to produce antifungal antibiotics in vitro [16]. Due to their metabolic diversity, actinomycetes are considered a good source of lytic enzymes, antibiotics, and other bioactive metabolites.

\section{Actinmycorrhizal plants}

These plants are characterized by formation in their roots nitrogen fixation nodules in combination with actinomycetes like Frankia sp. It was mentioned that a novel antibiotic called calcimycin was produced by Frankia sp. [17].

\section{Hypersaline soil}

Hypersaline habitats are known as typical extreme environments which include saline lakes, saline soils and salterns. Hypersaline soils contain 9 to 23\% salts. Examples of actinomycetes genera that isolated from hypersaline soils and showed antifungal activity against Fusarium solani, Aspergillus niger, and Cryptococcus sp. were Streptomyces alboflavus, Nocardia sp., Micromonospora sp., and Streptomyces griseoflavus [3, 11]. While some actinomycetes showed antibacterial activity against Staphylococcus aureus and Escherichia coli were Streptomyces exfoliates, Streptomyces diasticus, Streptomyces albus, and Streptomyces albidoflavus [18].

\section{Limestone}

Limestone is different crystal form of $\mathrm{CaCO} 3$ and also known as a sedimentary rock which contains aragonite beside minerals calcite [19]. These hard conditions are very promising for isolation and screening for new isolates that produce novel bioactive compounds where Streptomyces sp. MBRL 10 showed antifungal activity against Rhizoctonia solani [20].

\section{Freshwater}

It was known in recent years that the value of freshwater as a source of actinomycetes where genus Streptomyces was dominant in the river water while genus Micromonospora was dominated in the sediments of the river. These actinomycetes have antifungal activity from this habitat and it might be new sources for antimycotic
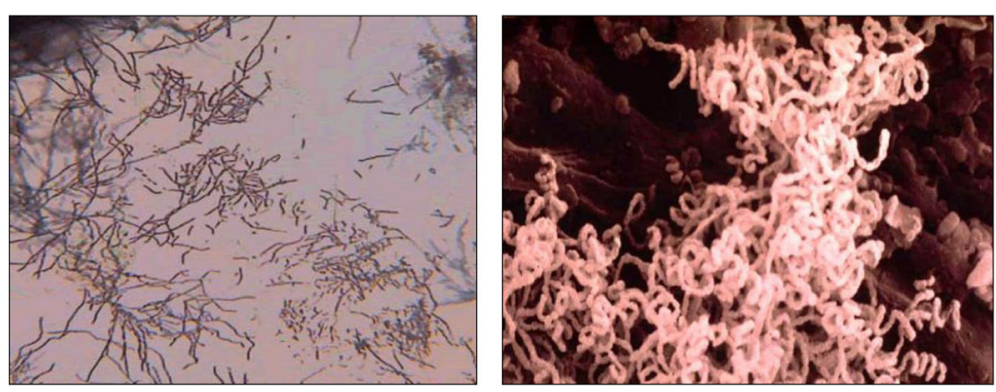

Fig. 1 Aerial mycelium of Streptomyces $\mathrm{sp}$. 

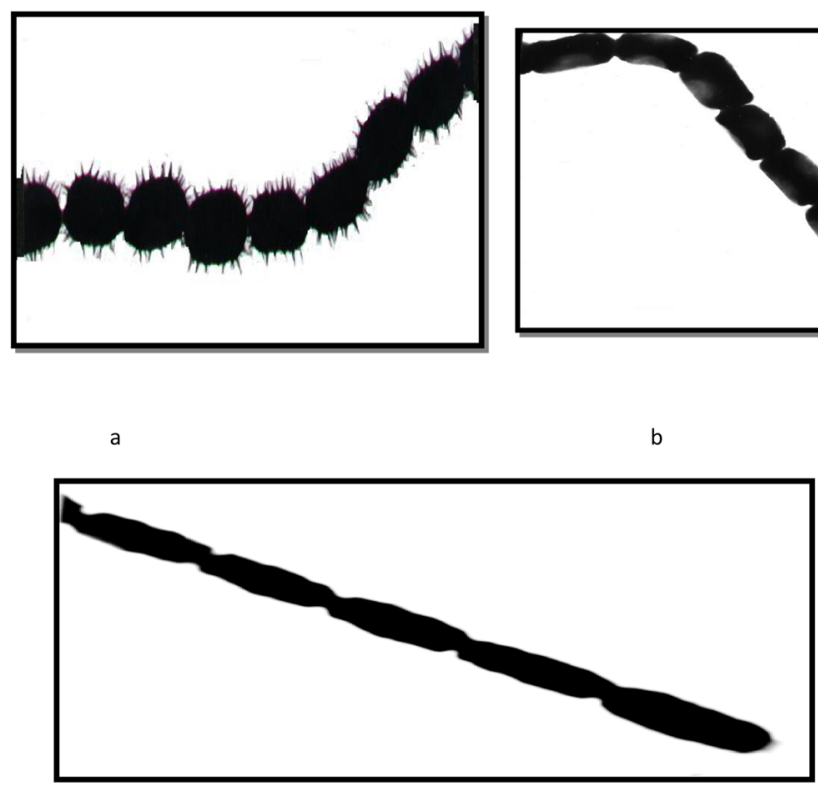

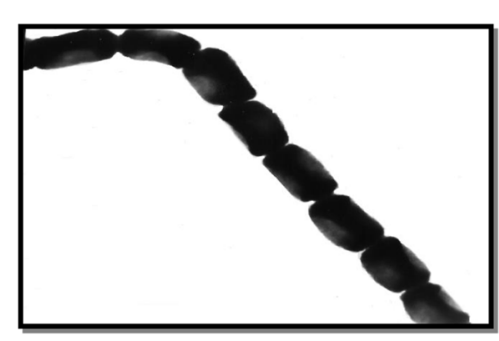

Fig. 2 Different types of spore surface of Streptomyces sp. a (spiny), b (smooth), and c (warty)

agents against yeast and molds that affect patients with the terminal disease [21].

\section{Marine}

The distribution of actinomycetes in the aquatic environment has been to a great extent undiscovered and the existence of primitive marine actinomycetes in the oceans stays a mystery. This is due to the absence of attempt in the discovering of marine actinomycetes taxa, while actinomycetes of terrestrial habitats have been, until lately, a useful source of new bioactive compound
[22]. Actinomycetes founded in unusual marine conditions, for example in marine deep-sea gas hydrate reservoirs and organic aggregates, where they are the main components of the microbial communities. In the Wadden Sea, the actinomycetes isolated from the marine organic aggregates in it exhibited high antagonistic activity within this community. These marine actinobacteria yield valuable compounds are used in the pharmaceutical industry [23]. Bonafide actinomycetes are widely distributed in different marine ecosystems not only exist in the oceans [22]. It was stated that marine actinobacteria

Table 1 Different groups of actinomycetes

\begin{tabular}{|c|c|}
\hline Section & Characteristics \\
\hline Nocardioformactinomycetes & $\begin{array}{l}\text { Aerobic, may be acid-alcohol fast; occur as rods, cocci, and branched filaments or form substrate and aerial } \\
\text { mycelium that fragment; wall chemotype IV; contain mycolic acids. }\end{array}$ \\
\hline $\begin{array}{l}\text { Actinomycetes with multilocular } \\
\text { sporangia }\end{array}$ & Aerobic to facultatively anaerobic; mycelium divides in all planes, no aerial hyphae, wall chemotype III. \\
\hline Actinoplanetes & $\begin{array}{l}\text { Aerobic sporoactinomycetes, nonmotile, spores may be enclosed within vesicles; no aerial mycelium; wall } \\
\text { chemotype II; whole-organism hydrolysates contain arabinose and xylose. }\end{array}$ \\
\hline Streptomycetesand related genera & Aerobic sporoactinomycetes; form an extensively branched substrate and aerial mycelium. \\
\hline Thermomonospora and relatedgenera & $\begin{array}{l}\text { Aerobic spordactinomycetes; form an extensively branched substrate and aerial mycelium, both of which } \\
\text { may carry single of chains of spores; spores either motile or non-motile; wall chemotype III }\end{array}$ \\
\hline Thermoactinomycetes & $\begin{array}{l}\text { The stable filaments produce aerial growth. Single spores (endospores) are formed on both aerial and } \\
\text { vegetative filaments. All species are thermophilic. The cell wall contains meso-DAP but no characteristic } \\
\text { amino acids or sugars. }\end{array}$ \\
\hline Other genera & They all produce aerial growth-bearing chains of spores \\
\hline
\end{tabular}


give a revelation of new classes of therapeutics that give the medications expected to support us for the following several years in our fight against drugresistant infectious diseases [24]. Marine actinomycetes produced excessive antibiotics with diverse chemical structures. Actinomycetes account for more than $45 \%$ of all bioactive metabolites discovered in nature [25]. Marine actinomycetes are very important microorganisms because of their significant role in both biological and biotechnological applications. Till now, there are 83 species of actinomycetes that belongs to 28 genera that have been isolated from marine habitats and most of them are new to science. When more deep-sea studies are done, the diversity of the marine actinomycetes will be expanded [26]. About sixty-four of new secondary metabolites produced by marine streptomycetes demonstrate high antimicrobial and anticancer activities. Aside from this, diverse enzymes and enzyme inhibitors were revealed from the marine streptomycetes. Furthermore, a portion of these novel compounds after clinical investigation have not demonstrated any toxicity and side effects $[27,28]$.

\section{Sponges}

As a noteworthy source of novel natural bioactive compounds, marine sponges harbor a lot of microbes in their tissues that can amount to forty percent of their biomass and it is widely believed that huge numbers of sponge's products are produced by symbiotic microorganisms [29]. Marine sponges are one of the basic parts of deepsea communities. They have developed specific relationships with various microorganisms and these relationships have ecological and biological importance. New actinomycete taxa have been detected in the Great Barrier Reef sponges, and also in the Mediterranean sponges where they produced different bioactive compounds [30].

\section{Volcanic cave-hot spot}

Volcanic caves have been minimally concentrated for their potential as sources of new bioactive compounds and microbial species with new scaffolds. Volcanic cave microbiology from Canada recommends that this specific habitat has extraordinary potential for the isolation of new bioactive secondary substances. Beutenbergia cavernae, a new genus actinomycete and Agromyces subbeticus isolated from southern Spain cave [31], where these new isolates have antimicrobial activities against a variety of resistant pathogens from [32].

\section{Desert}

The desert biome is viewed as a special, underinvestigated source of novel actinobacterial diversity, with countless microorganisms found in soil samples got from hyper-arid areas of the Atacama Desert [33]. Because of large amounts of oxidation, the soil inside the extreme hyper-arid area is drained in natural material and comprises of low levels of culturable bacteria; so, the Yungay region of the Atacama Desert gives a promising setting to explore the survival of microorganisms in states of extraordinary aridity [34]. A significant number of these metabolites have antimicrobial activities and can be developed as therapeutic agents. It is additionally trusted that the desert soil may harbor an extensive populace of halophilic and alkaliphilic actinomycetes [35].

\section{Air}

The ability of actinomycetes spores to be in the air was detected where air contains different types of their spores. It was stated that spores of airborne actinomycetes like Nocardia sp. are responsible for different antimicrobial production $[36,37]$.

\section{Insects gut}

The digestive tracts of insects contain communities of symbiotic and transient microorganisms where these organisms provide novel bioactive microbial products [38]. Generally, insect gut microbiota provides a large addition to the nutrition host's insect, as cleared examples like termites, cockroaches, and aphids. Honeybees, Apis mellifera, are a fascinating model for investigations of gut microorganisms due to the complex digestive tract. Streptomyces sp. sometimes could become the main organism in the bee guts. Species of Nocardiopsis were also identified in the gut of bee and characterized by the expression of an antibiotic biosynthetic gene [39]. The bioactive compounds produced by actinomycetes were specific against bee indigenous Bacillus strains furthermore two drugresistant Gram +ve human pathogens. Nocardiopsis alba is a rare actinomycete isolated from the honeybee gut. Phenazine produced by Nocardiopsis alba

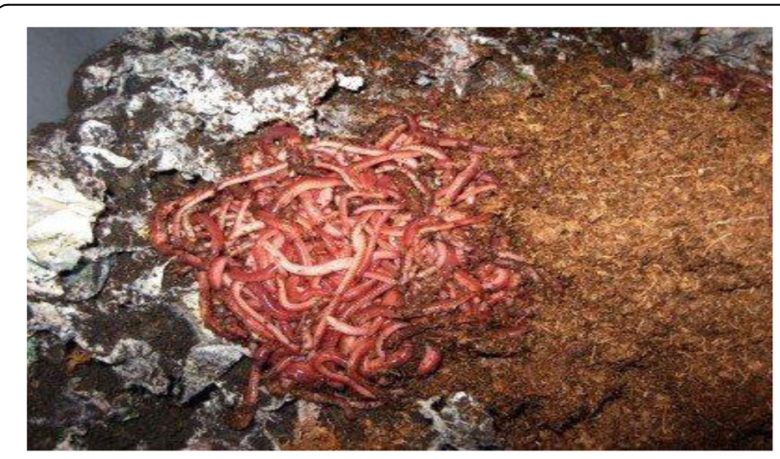

Fig. 3 Earthworm casting 
Table 2 Numbers of actinomycetales species, including the all rare actinos, known to produce bioactive metabolites, are summarized [45]

\begin{tabular}{|c|c|c|c|}
\hline Actinomycetales species & No. & Actinomycetales species & No. \\
\hline \multicolumn{2}{|l|}{ Streptomycetaceae } & \multicolumn{2}{|l|}{ Thermomonosporaceae } \\
\hline Streptomyces & 8000 & Actinomadura & 345 \\
\hline Streptoverlicillium & 258 & Saccharothrix & 68 \\
\hline Kitasatosporia & 37 & Microbispora & 54 \\
\hline Chainia & 30 & Actinosynnema & 51 \\
\hline Microellobosporia & 11 & Nocardiopsis & 41 \\
\hline Nocardioides & 9 & Microtetraspora/Nonomuria & $26 / 21$ \\
\hline \multicolumn{2}{|c|}{ Micromonosporaceae (Actinoplanetes) } & Thermomonospora & 19 \\
\hline Micromonospora & 740 & Micropolyspora/Faenia & $13 / 3$ \\
\hline Actinoplanes & 248 & Thermoactinomyces & 14 \\
\hline Dactylosporangium & 58 & Thermopolyspora & 1 \\
\hline Ampullariella & 9 & Thermoactinopolyspora & 1 \\
\hline Glycomyces & 2 & \multicolumn{2}{|l|}{ Mycobacteriaceae (Actinobacteria) } \\
\hline Catenuloplanes & 3 & Nocardia & 357 \\
\hline Catellatospora & 1 & Mycobacterium & 57 \\
\hline \multicolumn{2}{|l|}{ Pseudonocardiaceae } & Arthrobacter & 25 \\
\hline Saccharopolyspora & 131 & Brevibacterium & 17 \\
\hline Amycalotopsis/Nocardia & $120 / 357$ & Proactinomyces & 14 \\
\hline Kibdellosporangium & 34 & Rhodococcus & 13 \\
\hline Pseudonocardia & 27 & \multicolumn{2}{|l|}{ Other (unclassified) species } \\
\hline Amycolata & 12 & Actinosporangium & 30 \\
\hline Saccharomonospora & 2 & Microellobosporia & 11 \\
\hline Actinopolyspora & 1 & Frankia & 7 \\
\hline \multicolumn{2}{|c|}{ Streptosporangiaceae (Maduromycetes) } & Westerdykella & 6 \\
\hline Streptosporangium & 79 & Kitasatoa & 5 \\
\hline Streptoalloteichus & 48 & Synnenomyces & 4 \\
\hline Spirillospora & 11 & Sebekia & 3 \\
\hline Planobispora & 10 & Elaktomyces & 3 \\
\hline Kutzneria & 4 & Excelsospora & 3 \\
\hline \multirow[t]{7}{*}{ Planomonospora } & 2 & Waksmania & 3 \\
\hline & & Alkalomyces 1 & 1 \\
\hline & & Catellatospora 1 & 1 \\
\hline & & Erythrosporangium & 1 \\
\hline & & Streptoplanospora & 1 \\
\hline & & Microechinospora & 1 \\
\hline & & Salinospora & 1 \\
\hline
\end{tabular}

could add to its capacity to temporarily survive under anaerobic conditions that occur in honeybee guts [40].

\section{Earthworm castings}

The earthworm casting (Fig. 3) has rarely been investigated for actinomycetes having antimicrobial activity and industrial enzymes. The casting activity led to nutrition and enrichment in soil. The earthworm redistributes organic matter within the soil, where it leads to an increase of the permeability and microbial activity by its burrowing and feeding activity. The dominant genera were Streptomyces followed by Streptosporangium. 


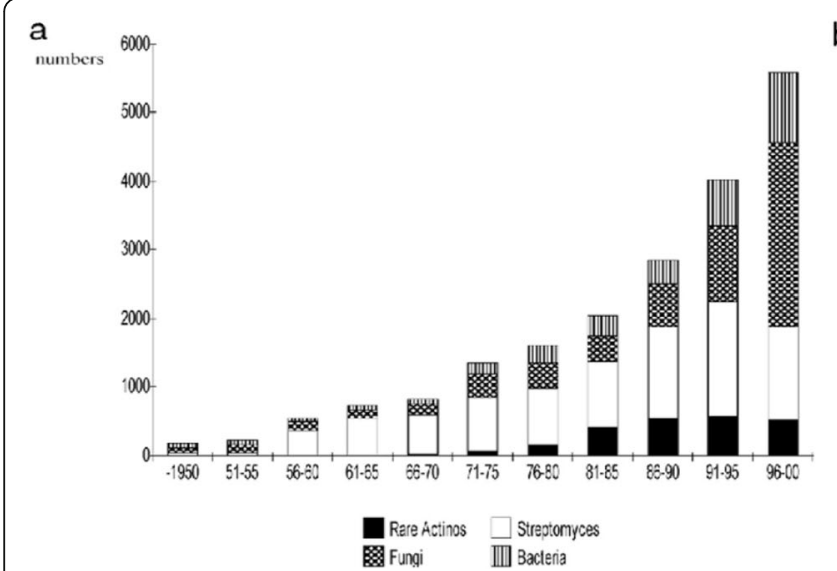

b

Fig. 4 Distribution of the discovered antibiotics according to their origin a (number), and $\mathbf{b}$ (percentage) [48]

Streptomyces from casting was antagonistic to wood degrading fungi. Actinomycetes from casting have wide application in human and veterinary medicines respectively [41].

\section{Goat feces}

Most actinobacteria are not obligate pathogens but true inhabitants of the environment. A symbiotic interaction with actinomycetes is essential for the survival and reproduction of many insects. Streptomycetes species appear to protect European beewolf offspring against infection by pathogens. In goat feces, the dominant species are Oerskovia and Nocardiopsis, where they produce larger numbers of antifungals than the antibacterial agent. Antibiotics like monensin and flavomycin produced by Streptomyces species have been used for growth-promoting in ruminants [42].

\section{Endophytic actinomycetes}

Endophytes are microorganisms that live for the entire or part of their life history inside plant tissues [43]. Because of these long held affiliations, endophytic microorganisms and plants have grown great information exchange. Endophytic actinomycete produced bioactive compounds were used as biocontrol agents like compounds produced by Nocardia globerula to control Helminthosporium solani pathogen which causes silver scurf illness in potato.

Streptomycetes sp. compounds showed antifungal activity. Ansacarbamitocins were separated from actinomycetes strain Amycolatopsis CP2808 which has a place with family pseudonocardiaceae. Ansamitocin is a group of ansamycin antibiotics that demonstrates strong antitumor action [44]. Ansamitocin was produced by endophytic actinomycetes Nocardia sp.

Table 3 List of some antibiotics produced by Streptomyces sp. [47]

\begin{tabular}{|c|c|c|c|}
\hline Streptomyces sp. & Antibiotic & Streptomyces sp. & Antibiotic \\
\hline S. orchidaccus & Cycloserin $n$ & S. erythraeus & Erythromycin \\
\hline S. oriantalis & Vancomycin & S. vensuella & Chloramphenicol \\
\hline S. fradiae & Neomycin, actinomycin, fosfomycin, dekamycin & S. aureofaciens & Chlortetracycline, dimethylchlor \\
\hline S. nodosus & Amphotricin B & S. ambofaciens & Spiramycin \\
\hline S. noursei & Nistatin & S. avermitilis & Avermicin \\
\hline S. mediterranei & Rifampin & S. alboniger & Puromycin \\
\hline S. griseus & Streptomycin & S. niveus & Novobicin \\
\hline S. knanamyceticus & Kanamycin & S. platensis & Platenmycin \\
\hline S. tenebrarius & Tobramycin & S. roseosporus & Daptomycin \\
\hline S. spectabilis & Spectinomycin & S. ribosidificus & Ribostamycin \\
\hline S. viridifaciens & Tetracycline & S. garyphalus & Cycloserine \\
\hline S. lincolensis & Lincomycin, clindamycin & S. vinaceus & Viomycin \\
\hline S. rimosus & Oxytetracyclin & S. clavuligerus & Cephalosporin \\
\hline
\end{tabular}


Table 4 List of the bioactive compounds derived from actinobacteria showed antibacterial and antitumor activities [41]

\begin{tabular}{|c|c|c|}
\hline Bioactive compound & Species & Activity \\
\hline Abyssomicin & Verrucosispora sp. & $\begin{array}{l}\text { Antibacterial } \\
\text { and antitumor }\end{array}$ \\
\hline Actinofuranones $\mathrm{A}-\mathrm{B}$ & Streptomyces sp. & $\begin{array}{l}\text { Antibacterial } \\
\text { and antitumor }\end{array}$ \\
\hline Analogs-metacycloprodigiosin & Saccharopolyspora sp. & Anticancer \\
\hline Benzanthraaquinone & Chainia purpurogena & $\begin{array}{l}\text { Antibacterial } \\
\text { and antitumor }\end{array}$ \\
\hline Butenolides & Streptomyces sp. & Antitumor \\
\hline Mechercharmycin & Thermoactinomyces sp. & Antitumor \\
\hline Diphosphatidylglycerol & Micromonospora sp. & Antitumor \\
\hline
\end{tabular}

\section{Secondary metabolites from actinomycetes}

Secondary metabolites created by Actinomycetes display an incredible number of diverse biological effects, besides the antimicrobial activities. The order Actinomycetales are responsible for the production of bioactive compounds with a highly record of more than 10,000 antimicrobial agents in pharmaceutical use (Table 2) [45].

\section{Antibiotics}

Antibiotics are an exceptional sort of chemotherapeutic agent produced by living organisms; bacteria, fungi, and actinomycetes, which in little amounts can hinder the growth of microorganisms or even kill them. Antibiotics are defined as low molecular weight organic compounds produced by microorganisms [46]. About seventy-five percent of antibiotics mainly antibacterials are produced by actinomycetes. Huge numbers of antibacterials show an expansive range of activities and various systems of activity. They demonstrated high intensity against a huge number of Gram +ve and Gram -ve bacteria [47]. Historically, the origin of the biggest number of the new antibiotic drugs was streptomycetes when comparing with bacteria and fungi (Fig.4) $[45,48]$. This order alone created about $45 \%$ of the known bioactive metabolites; more than ten thousand compounds were isolated from different actinomycetales species, about thirty-four percent from Streptomyces and eleven percent from the other actinomycetes [49].

Disclosure of new antibiotics secreted by streptomycetes continue for instance; mediomycins A, B, and clethramycin, were isolated from Streptomyces mediocidicus ATCC23936 and Streptomyces malaysiensis DSM4137 respectively show a wide spectrum of antifungal activity [50].

Polyketides are very important natural products because of their pharmaceutical applications. Instances of such polyketides are erythromycin (antibacterial), nystatin (antifungal), furthermore avermectin (antiparasitic). All the previous antibiotics have been produced by Streptomyces sp. which are considered as the principle producers of antibiotics (Table 3) [47].

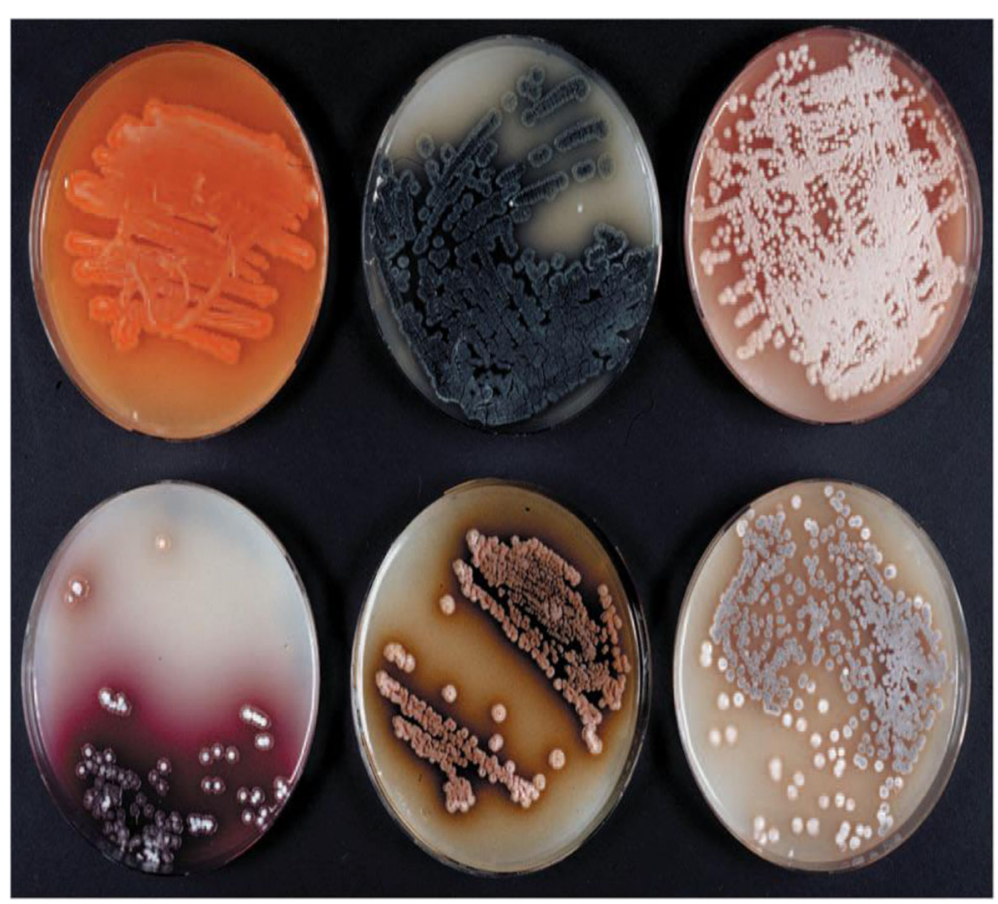

Fig. 5 Production of pigmented secondary metabolites by Streptomyces colonies [63] 


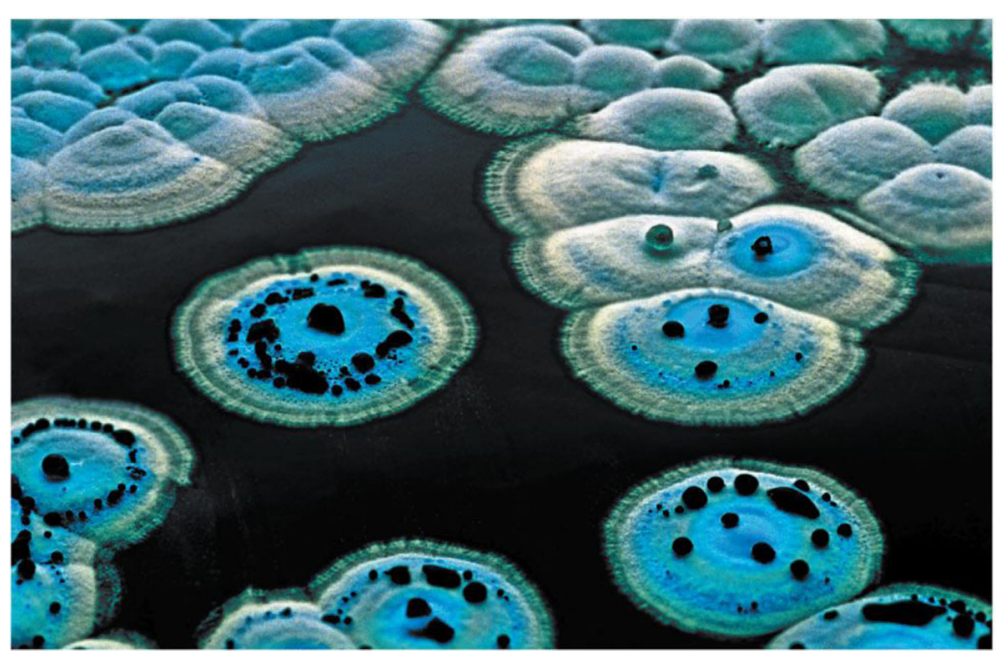

Fig. 6 A panoramic view of Streptomyces coelicolor including the blue antibiotic actinorhodin is excreted into the medium and into aqueous droplets on the hydrophobic surface of the colony [63]

\section{Biopesticide agents}

Microorganisms including which are antagonistic to insects are used to naturally control them. Actinomycetes produce insecticidal active compounds used in biological control of house fly Musca domestica [51]. The death of larval and pupal stages were high coming to up to ninety percent after using actinomycetes insecticide [52]. Actinomycetes were adequately used for controlling mosquito Culex quinquefasciatus [45, 47].

\section{Plant growth hormone}

Actinomycetes have been used for the improvement plant growth by the production of plant growth hormones for example auxins and gibberellin-like compounds [52, 53]. Actinomycetes produced Indole-3acetic acid (IAA) which is the main form of auxin; this compound is responsible for cell division, elongation, and differentiation.

\section{Antitumor compounds}

Streptomycetes are differentiated groups that can create distinctive cytotoxic compounds which have anticancer activity [54-56]. The produced compound in Table 4 showed significant activity against different malignant cell lines [41]. Mitomycin is a natural product that contains different functional groups, like aminobenzoquinone and aziridine ring system. Mitomycin $\mathrm{C}(\mathrm{MC})$ was produced by Streptomyces lavendulae and has been generally utilized clinically for antitumor treatment $[57,58]$.

\section{Antiviral agents}

Streptomyces lavendulae produced complestatins which are known as peptides. They did not show inhibitory activity against HIV enzymes, where these peptides act by the interaction with the cell surface molecules of the target cells and inhibiting the adsorption of human immunodeficiency virus type $1(\mathrm{HIV}-1)$ to the cells [59] (Table 4). A list of the bioactive compounds derived from actinobacteria showed antibacterial and antitumor activities [41].

Streptomyces chromofuscus produced protease inhibitor (PISC-2002) from culture supernatants of it. PISC2002 plays an important role as an antiviral agent against influenza virus A/Rostock/34 (H7N7) [60]. Streptomyces sp. produced pimprinine, which is an extracellular alkaloid. Pimprinine shows significant physicochemical properties, antimicrobial activities, anticonvulsant activity and also shows antiviral activity against Enterovirus 71 (EV71) [61].

\section{Pharmacological compounds}

Vitamin B12 is a very important vitamin of the B complex (B1, B2, B3, B6, and folic acid) group. It was first recorded in 1948 from Streptomyces griseus. There is no source of this vitamin except microbial synthesis [62].

\section{Pigments}

Actinomycetes are characterized by the different production of pigments on natural or synthetic media. These pigments are usually blue, violet, red, rose, yellow, green, brown, and black. The pigments might be diffuse into the medium or they might be retained in the mycelium (Fig. 5) [63]. Actinomycetes had known to be produced different sorts of antibiotics, and additionally, these antibiotics include numerous pigments [64]. Melanins are regularly used in pharmacology and cosmetics. 
Table 5 Commercial enzymes produced by actinomycetes with their application [41]

\begin{tabular}{|c|c|c|c|}
\hline Enzyme & Actinomycetes strains & Use & Industrial of application \\
\hline \multirow[t]{5}{*}{ Protease } & \multirow[t]{5}{*}{ S. galbus } & Detergents & Detergents \\
\hline & & Cheese making & Food \\
\hline & & Clarication-low calorie beer & Brewing \\
\hline & & Dehiding & Leather \\
\hline & & Treatment of blood clot & Medicine \\
\hline Cellulase & S. actuosus & $\begin{array}{l}\text { Removal of stains, denim nishing, } \\
\text { soening of detergent }\end{array}$ & $\begin{array}{l}\text { Deinking, modication of } \\
\text { bers, paper and pulp } \\
\text { Denim nishing, soening } \\
\text { of cotton }\end{array}$ \\
\hline \multirow[t]{4}{*}{ Lipase } & \multirow[t]{4}{*}{ S. griseochromogenes } & Removal of stains & Detergent \\
\hline & & Stability of dough and conditioning & Baking \\
\hline & & Cheese avoring & Dairy \\
\hline & & Deinking, cleaning & Textile \\
\hline \multirow[t]{3}{*}{ Xylanase } & \multirow[t]{3}{*}{ S. rameus } & Conditioning of dough & Baking \\
\hline & & Digestibility & Animal feed \\
\hline & & Bleach boosting & Paper and pulp \\
\hline Pectinase & S. fradzae, S nztrosporeur & Clarication, mashing & Beverage \\
\hline \multirow[t]{5}{*}{ Amylase } & \multirow[t]{5}{*}{ S. aureofasciculus, S. galilaeus } & Soness of bread soness & Detergent \\
\hline & & Removal of stains volume & Baking \\
\hline & & Deinking, drainage improvement & Paper and pulp \\
\hline & & Production of glucose and fructose syrups & Starch industry \\
\hline & & Removal of starch from woven fabrics & Textile \\
\hline Glucos oxidase & Streptomyces sp. & Strengthening of dough & Baking \\
\hline Lipoxygenase & Streptomyces sp. & Bread whitening & Baking \\
\hline Phytase & S. ambofaciens, S. lienomycini. & Phytate digestibility & Animal feed \\
\hline Peroxidase & Thermomonospora fusca, S. viridosporus & Removal of excess dye & Textile \\
\hline$\beta$-galactosidase & Streptomyces sp. & $\begin{array}{l}\text { Enzymatic hydrolysis of lactose either } \\
\text { from milk/whey or pure lactose }\end{array}$ & Dairy \\
\hline L-asparaginase & $\begin{array}{l}\text { S. aureofasciculus, S. canus, S. chattanoogenesis, } \\
\text { S. hawaiiensis, S. olivoviridid, S. orientalis, S. plicatus }\end{array}$ & $\begin{array}{l}\text { Reduce the formation of acrylamide, } \\
\text { a carcinogen found in starchy food products }\end{array}$ & Food industry \\
\hline L-glutaminase & S. rimosus, S. galbus & Flavor enhancing agent in food & Food industry \\
\hline Keratinase & Doretomycetes microsporus & Animal feed & Poultry industry \\
\hline Petinase & Thermomonospora flisca S. viridochromogenes & Retting and degumming of fiber crops & Textile industry \\
\hline
\end{tabular}

Streptomyces virginiae produced the highest level of pigment in peptone-yeast extract-iron followed by tyrosine liquid medium. The pigment-producing actinomycete Streptomyces hygroscopicus showed antibacterial activity against many drug-resistant pathogens like methicillin-resistant Staphylococcus aureus (MRSA), vancomycin-resistant Staphylococcus aureus (VRSA), and extended-spectrum $\beta$-lactamases (ESBL) strains. Streptomyces species produced yellowish antibiotic pigment 4-hydroxynitrobenzene. Where the yellow pigment was extracted in chloroform and showed activity against Bacillus subtilis and Shigella shiga. Microbial pigments have antibiotic or anticancer activities and are also safe for human utilization. Few of them are also demonstrated as nourishment grade pigments. They are easy to produce and are economic too $[65,66]$. Streptomycetes is a major industrially important class, which have the ability to produce numerous antibiotics and pigments. The ability of these organisms to produce pigments depends on the various conditions of nutrition and cultivation where it can be greatly increased or completely lost. So, it is very important to improve the right combination of different cultural conditions to encourage growth and pigment production. A biological pigment actinorhodin is produced by Streptomyces coelicolor, Streptomyces violaceusruber, and Streptomyces 


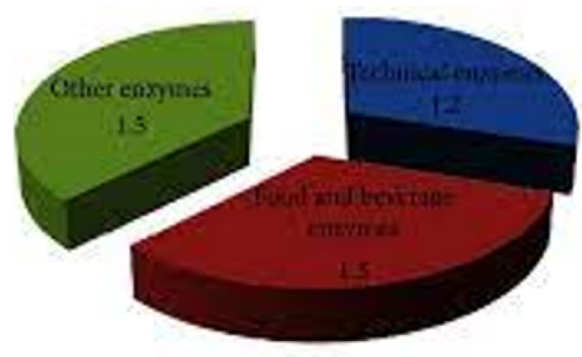

(a)

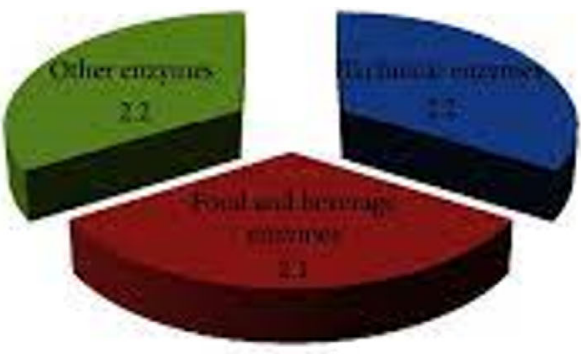

(b)

Fig. 7 Global enzyme industry market in the years a (2011), and b (2016) [72]

lividans. It is blue in color and based on the pH (Fig. 6) [67]. This pigment has different application such as an antibiotic against Gram +ve bacteria, an indicator in laboratory agents because of its ability to show special colors in acid and alkali medium and finally, actinorhodin can be used in the food industry during making beverages, desserts, etc. and might be even in cosmetic industry. The complete scope of pigment's application has not been yet explored [68].

\section{Commercial enzymes}

The value of commercial enzymes has been expanded considerably with their different uses in pharmaceutical, food, and detergents industry. Actinomycetes have a different active enzyme which is able to catalyze different biochemical reactions with new enzymes. The applications of few commercial enzymes are listed in Table 5 [41].

Streptomyces species produced important enzymes like amylase, protease, and cellulose which have commercial applications in different industries [69]. L-glutaminase, Lasparaginase, and $\alpha$-galactosidase have an effective role in biocycling of carbon and nitrogen in natural water and sediments. L-glutaminase and L-asparaginase showed antitumor activities and were produced by marine streptomycetes [70, 71]. The global industrial enzyme market has been increased continuously because of various mergers and acquisitions (Fig. 7). Food and beverage enzymes have great attention in these decades. There are additional increments in patent number in the decades in straight scale which are given in Fig. 8 [72].

\section{Enzyme inhibitors}

Enzyme inhibitors have gotten expanding consideration as valuable tools, not just for the study of enzyme structures and reaction mechanisms yet additionally for potential usage in the pharmacological industry [73]. Marine actinomycetes are promising sources for enzyme inhibitor production $[74,75]$, it was reported that different types of

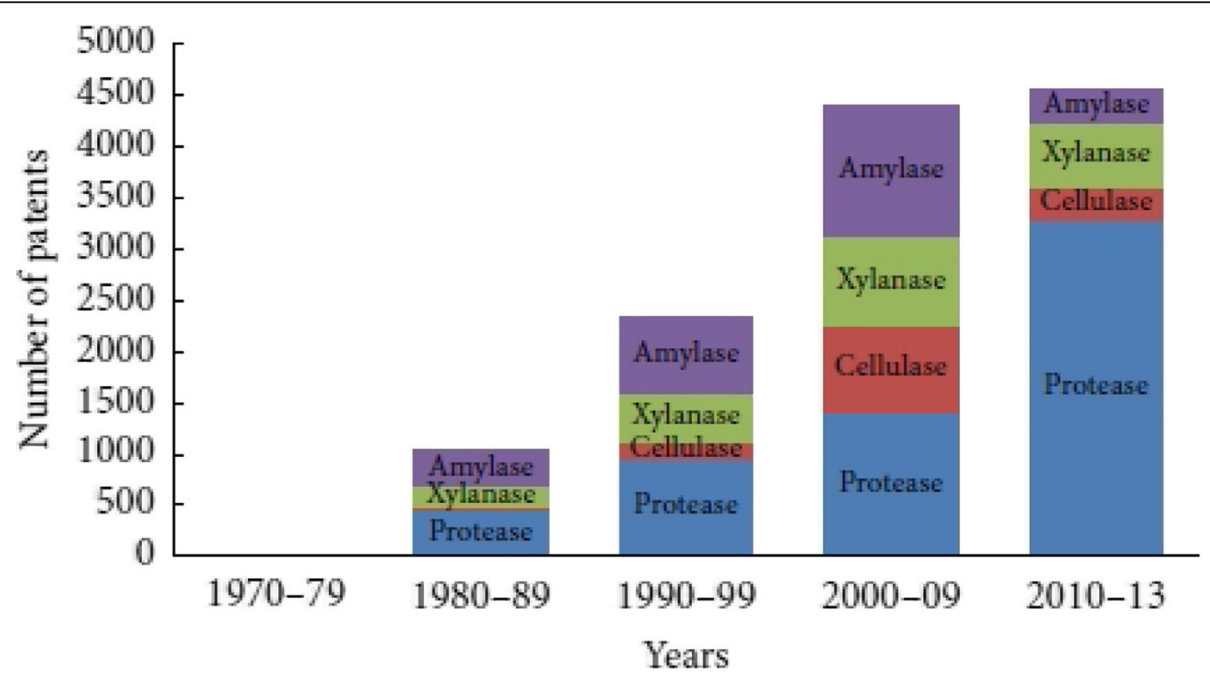

Fig. 8 Growth in number of patents issued for important industrial enzymes over past few decades [72] 
enzyme inhibitors like N-acetyl--D-glucosaminidase, pyroglutamyl peptidase, and $\alpha$-amylase inhibitors are produced from marine actinomycetes. Amylase inhibitors are starch blocker since they contain substances that keep dietary starches from being consumed by the body. The inhibitors might be helpful for weight loss.

Alpha-amylase inhibitors are produced by Streptomyces corchorushii and Streptomyces sp. CC5 respectively [75]. Streptomyces toxytricini produced lipstatin, which is a very exceptional inhibitor of pancreatic lipase [76].

\section{Anti-inflammatory compounds}

Saphenic acid and lipomycin were found to have antiinflammatory activity that is produced by marine actinomycetes [77]. Also, it was stated that Micromonospora sp. produced bioactive compounds with anti-inflammatory activity along with antimicrobial activity [78]. Streptomyces arenicola also produces the anti-inflammatory metabolites cyclomarin $\mathrm{A}$ and $\mathrm{C}$, where it was reported that cyclomarin A has anti-tuberculosis and anti-malaria activity [79]. It has been noticed that swelling was decreased when cyclomarin A was managed topically or intraperitoneally [80].

\section{Single-cell protein feed}

Marine actinomycetes can be utilized as fishmeal. Actinomycetes can produce some secondary metabolites which may improve the development of young fish and shrimp. Some of these metabolites for example boromycin, aplasmomycin [81], and regular amino acids like alanosine, amino dichlobutyric acid, azaleucine, and 4-oxalysine [82]. Young prawns and shrimps fed on actinomycetes incorporated feed indicated a higher development rate, more food conversion efficiency, and higher protein content [82]. So, among the unusual protein sources, single-cell protein of microbial origin seems to be a promising substitute for fishmeal, which can supplant up to 25 to $50 \%$ fishmeal in aquaculture operations.

\section{Biosurfactant}

A biosurfactant is a surface-active molecule produced mainly by microorganisms. The term refers to compounds having some influence on interfaces. The evaluation of biosurfactants is carried out through surface tension measurements. In the literature, the terms surfactant and emulsifier are frequently used interchangeably [83, 84].

Biosurfactants have numerous advantages due to their specificity, biodegradability, and less toxicity. Also, the effectiveness of these biosurfactants to work under extreme conditions of temperature, $\mathrm{pH}$, and salinity. Actinomycetes play an important vital role in the production of bioemulsifiers. Trehalose dimycolates produced by certain actinomycetes like Nocardia sp. [85]. Also,
Streptomyces griseoflavus and Nocardiopsis A17 were produced numerous biosurfactants [86].

\section{Conclusion}

The utilization of Actinomycetes as a hotspot for new bioactive optional metabolites in its earliest stages. The antagonistic Actinomycetes evidence that the ecosystem is an important source of biologically active secondary metabolites. Finding powerful secondary metabolite producers like Actinomycetes is an interesting and challenging platform for scientists. Despite of growing under extraordinary conditions, members of Actinomycetes produce industrially valuable compounds, for example, enzymes, antibiotics, and pigments. The various ecological habitats demonstrate the existence of Actinomycetes species in specific microbial niches. However, the ecological habitat is underexplored and yet to be investigated for unknown, rare Actinomycetes diversity.

\section{Acknowledgements}

Not applicable

\section{Authors' contributions}

All authors certify that they have participated sufficiently in contributing to the intellectual content, concept, writing the manuscript and all authors have read and approved the manuscript, and ensure that this is the case M.S.S. collected the material and wrote the review, S.A.A. (corresponding author) confirms that all listed authors have approved the manuscript before submission, including the names and order of authors, and that all authors receive the submission and all substantive correspondence with editors, as well as the full reviews, and S.S.M. formatted the review.

Funding

Not applicable

Availability of data and materials Not applicable

\section{Declarations}

Ethics approval and consent to participate

Not applicable

\section{Consent for publication}

Not applicable

\section{Competing interests}

The authors declare that they have no competing interests.

Received: 17 December 2020 Accepted: 29 March 2021 Published online: 12 May 2021

\section{References}

1. Berdy J (2012) Thoughts and facts about antibiotics: where we are now and where we are heading. J Antibiot 65(8):385-395. https://doi.org/10.1038/ja.2 012.27

2. Manivasagan P, Venkatesan J, Sivakumar K, Kim SK (2013) Marine actinobacterial metabolites: current status and future perspectives. Microbiol Res 168(6):311-332. https://doi.org/10.1016/j.micres.2013.02.002

3. Mohan KD, Rajamanickam U (2018) Biodiversity of actinomycetes and secondary metabolites. Inn Orig Inter J Sci 5(1):21-27

4. Elmallah MIY, Cogo S, Constantinescu A, Esposito SE, Abdelfattah MS, Micheau O (2020) Marine actinomycetes-derived secondary metabolites overcome TRAIL-resistance via the intrinsic pathway through down regulation of survive in and XIAP. Cells 9(8):1760-1778. https://doi.org/10.33 90/cells9081760 
5. Dewi TK, Agustiani D, Antonius S (2017) Secondary metabolites production by actinomycetes and their antifungal activity. Kn E Life Sci:256-264. https://doi.org/10.18502/kls.v3i4.713

6. Mincer TJ, Jensen PR, Kauffman CA, Fenical W (2002) Widespread and persistent populations of a major new marine actinomycete taxon in ocean sediments. Appl Environ Microbiol 68(10):5005-5011. https://doi.org/10.112 8/AEM.68.10.5005-5011.2002

7. Dror B, Jurkevitch E, Cytryn E (2020) State-of-the-art methodologies toidentify antimicrobial secondary metabolites in soil bacterial communities-a review. Soil Biol Biochem 147:107838-107847. https://doi. org/10.1016/j.soilbio.2020.107838

8. Bull AT, Ward AC, Goodfellow M (2002) Search and discovery strategies for biotechnology: the paradigm shift. Microbiol Mol Biol Rev 64:573-606. https://doi.org/10.1128/mmbr.64.3.573-606.2000

9. Dhanasekaran D, Rajkumar G, Sivamani P, Selvamani S, Panneerselvam A Thajuddin N (2005) Screening of salt pans actinomycetes for antibacterial agents. Inter J Microbio 2:62-66

10. Salwana R, Sharmab V (2020) Molecular and biotechnological aspects of secondary metabolites in actinobacteria. Microbiol Res 231:126374. https://doi.org/10.1016/j.micres.2019.126374

11. Karuppiah P, Mustaffa M (2013) Antibacterial and antioxidant activities of Musa sp. leaf extracts against multidrug resistant clinical pathogens causing nosocomial infection. Asian Pac J Trop Biomed 3(9):737-742. https://doi. org/10.1016/S2221-1691(13)60148-3

12. Al-Ansari M, Kalaiyarasi M, Almalki MA, Vijayaraghavan P (2020) Optimization of medium components for the production of antimicrobial and anticancer secondary metabolites from Streptomyces sp. AS11 isolated from the marine environment. JKSU - Science 32(3):1993-1998. https://doi.org/10.1016/j. jksus.2020.02.005

13. Goodfellow M, Williams T (1983) Ecology of actinomycetes. Annu Rev Microbiol 37(1):189-216. https://doi.org/10.1146/annurev.mi.37.100183.00120

14. Kuster E, Williams ST (1964) Production of hydrogen sulphide by Streptomyces and methods for its detection. Appl Microbiol 12(1):46-52. https://doi.org/10.1128/AM.12.1.46-52.1964

15. Kumar N, Singh RK, Mishra SK, Singh AK, Pachouri UC (2010) Isolation and screening of soil actinomycetes as source of antibiotics active against bacteria. Inter J Microbio Res 2(2):12-16. https://doi.org/10.9735/0975-52 76.2.2.12-16

16. Gonzalez-Franco AC, Robles Hernande Z, NuñezBarrios A, Strap JL, Crawford DL (2009) Molecular and cultural analysis of seasonal Actinomycetes in soils from Artemisia tridentata habitat. Inter J Experim Botany 78:83-90

17. Daniel WU, Erin AG, Adam CJ, Carla SJ, Andrew J, Jones WS, Jaclyn MW (2011) Significant natural product biosynthetic potential of actinorhizal symbionts of the genus Frankia, as revealed by comparative genomic and proteomic analyses. Appl Environ Microbiol 11:3617-3625. https://doi.org/1 0.1128/AEM.00038-11

18. Nakade DB (2012) Biodiversity of Actinomycetes in hypersaline soils of Kolhapur district and their screening as potential antibiotic producer. India Res J Recent Sci 1:317-319

19. Quadri SR, Agsar D (2012) Antimicrobial attributes of rare actinobacteria detected from limestone quarries. Int J Pharm Bio Sci 3(3):137-147. https://doi.org/10.3389/fmicb.2015.00413

20. Tamreihao K, Salam N, Shamjetshabam BC, Khaidem A, Rajkumari L, Ningthoukhongjam J, Debananda SN (2016) Acido tolerant Streptomyces sp. MBRL 10 from limestone quarry site showing antagonism against fungal pathogens and growth promotion in rice plants. J King Saud Uni Sci 30(2): 143-152. https://doi.org/10.1016/j.jksus.2016.10.003

21. Rifaat HM (2003) The biodiversity of actinomycetes in the River Nile exhibiting antifungal activity. J Mediterran Ecol 4:3-4

22. Murti Y, Tarun A (2010) Marine derived pharmaceuticals development of natural health products from marine biodiversity. Inter J Chem Tech Res 1: 2198-2217

23. Kin SL (2006) Discovery of metabolites from marine actinomycetes. Curr Opin Microbiol 9:245-251. https://doi.org/10.1016/j.mib.2006.03.004

24. Vimal V, Rajan BM, Kannabiran K (2009) Antimicrobial activity of marine actinomycete, Nocardiopsis sp. VITSVK 5(FJ973467). Asi J Med Sci 1(2):57-63

25. Katarzyn J, Aexander R, Guspiel A, ZiemskaJ OJ (2018) Secondary metabolites of actinomycetes and their antibacterial, antifungal and antiviral properties. Pol J Microbiol 67(3):259-272. https://doi.org/10.21307/pjm-2018-048

26. Prave $P$, Faust W, Sitting W, Sukatsch DA (1987) Fundamentals of biotechnology. FRG, Weinheim
27. Mikami Y (2007) Biological work on medically important Nocardia species. Actinomycetolo 21(1):46-51. https://doi.org/10.3209/saj.SAJ210107

28. Roshan K, Koushik B, Vikas S, Pankaj K, Avijit T (2014) Actinomycetes: potential bioresource for human welfare: a review. Res J Chem Env Sci 2(3):5-16

29. Ouyang A, Chang Y (2011) A method to type the potential angucycline producers in actinomycetes isolated from marine sponges. Antonie Van Leeuwenhoek 99(4):807-815. https://doi.org/10.1007/s10482-011-9554-5

30. Selvan P, Ravikumar S, Ramu A, Neelakandan P (2012) Antagonistic activity of marine sponge associated Streptomyces sp. against isolated fish pathogens. Asi Pac J Trop Dis:724-728. https://doi.org/10.1016/S2222-1 808(12)60252-7

31. Jurado V, Kroppenstedt RM, Saiz-Jimenez C, Klenk HP, Mouniee D, Laiz L (2009) Hoyosella altamirensis gen. Sp. Nov., a new member of the order Actinomycetales isolated from a cave biofilm. Int J Syst Evol Microbiol 59(12):3105-3110. https://doi.org/10.1099/ijs.0.008664-0

32. Cheeptham N, Sadoway T, Rule D, Watson K, Moote P, Soliman ALC, Donkor KK, Horne D (2013) Cure from the cave: volcanic cave actinomycetes and their potential in drug discovery. Int J Speleol 42(1):35-47. https://doi.org/1 $0.5038 / 1827-806 \times .42 .1 .5$

33. OrtizM NJW, Nelson WM, Legatzki A, Byrne A, Yu A, Wing RA, Soderlund CA, Pryor BM, Pierson LS III, Maier RM (2013) Profiling bacterial diversity and taxanomic composition on speleothem surfaces in kartchner caverns. AZ Microb Ecol 65(2):371-383. https://doi.org/10.1007/s00248-012-0143-6

34. González I, Ayuso-Sacido A, Anderson A, Genilloud O (2005) Actinomycetes isolated from lichens: evaluation of their diversity and detection of biosynthetic gene sequences. FEMS Microbiol Ecol 54(3):401-415. https:// doi.org/10.1016/j.femsec.2005.05.004

35. Badji B, Zitouni A, Mathieu F, Lebrihi A, Sabaou N (2006) Antimicrobial compounds produced by Actinomadura sp. AC104 isolated from an Algerian Saharan soil. Can Microbiol 52(4):373-382. https://doi.org/10.1139/ w05-132

36. McNeil MM, Brown JM (1994) The medically important aerobic actinomycetes: epidemiology and microbiology. Clin Microbiol Rev 7:357417. https://doi.org/10.1128/cmr.7.3.357

37. Asana A, Ilhanb S, Sena B, Potoglu I, Cansu E, Ahmet F, Rasime C, Mevlut D, Suzan T, Oktena S, Tokurb S (2004) Airborne fungi and actinomycetes concentrations in the air of Eskisehir City (Turkey). Ind Built Environ 13(1): 63-74. https://doi.org/10.1177/1420326X04033843

38. Breznak JA (2004) Invertebrates-insects, in microbial diversity and bioprospecting. Amer Soc Microbio:191-203. https://doi.org/10.1128/9781 555817770.ch19

39. Kristufek V, Ravasz K (1993) Actinomycetes communities in earthworm guts and surrounding soil. Pedobiol 37:379-384

40. Teske A, Dhillon A, Sogin MI (2003) Genomic markers of ancient anaerobic microbial pathways: sulfate reduction, methanogenesis and methane oxidation. Biol Bull 204:186-191. https://doi.org/10.2307/1543556

41. Kumar R, Biswas K, Soalnki V, Kumar P, Tarafdar A (2014) Actinomycetes: potentia bioresource for human welfare: a review. Res J Chem Environ Sci 2(3):5-16

42. Tan H, Deng Z, Cao L (2009) Isolation and characterization of actinomycetes from healthy goat faeces. Lett Appl Microbiol 49(2):248-253. https://doi. org/10.1111/j.1472-765X.2009.02649.x

43. Hasegawa S, Meguro A, Shimizu M, Nishimura T, Kunoh H (2006) Endophytic actinomycetes and their interactions with host plants. Actinomycetolo 26(2):72-81. https://doi.org/10.3209/saj.20.72

44. Snipes CE, Duebelbeis DO, Olson M, Hahn DR, Dent WH (2007) The ansacarbamitocins: polar ansamitocin derivatives. J Nat Prod 70(10):15781581. https://doi.org/10.1021/np070275t

45. Sharma M, Dangi P, Choudhary M (2014) Actinomycetes: source, identification, and their applications. Int J Curr Microbiol App Sci 3(2):801-832

46. Adegboye MF, Babalola OO (2013) Actinomycetes: a yet inexhaustive source of bioactive secondary metabolites. In: Méndez-Vilas A (ed) Microbial pathogens and strategies for combating them: science, technology and education, pp 786-795

47. Hasani A, Kariminik A, Issazadeh K (2014) Streptomycetes: characteristics and their antimicrobial activities. Int J Adv Biol Biomed Res 2:63-75

48. Hong H, Samborskyy M, Usachova K, Schnatz K, Leadlay PF, Dickschat JS (2017) Sulfation and amidinohydrolysis in the biosynthesis of giant linear polyenes. Beilstein J Org Chem 13:2408-2415. https://doi.org/10.3762/bjoc.13.238

49. Baltz RH (2009) Daptomycin: mechanisms of action and resistance, and biosynthetic engineering. Curr Opin Chem Biol 13(2):144-151. https://doi. org/10.1016/j.cbpa.2009.02.031 
50. Hussain AA, Mostafa SA, Ghazal SA, Ibrahim SY (2002) Studies on antifungal antibiotic and bioinsecticidal activities of some actinomycete isolates. Afr J Mycol Biotechnol 10:63-80

51. Sundarapandian S, Sundaram MD, Tholkappian P, Balasubramanian V (2002) Mosquitocidal properties of indigenous fungi and actinomycetes against Culex quinquefasciatus say. J Biol Control 16:89-91

52. Bloemberg GV, Lugtenberg BJJ (2001) Molecular basis of plant growth promotion and biocontrol by rhizobacteria. Curr Opin Plant Biol 4(4):343352. https://doi.org/10.1016/\$1369-5266(00)00183-7

53. Persello-Cartieaux F, Nussaume L, Robaglia C (2003) Tales from the underground: molecular plant-rhizobacteria interactions. Review. Plant Cell Environ 26(2):189-199. https://doi.org/10.1046/j.1365-3040.2003.00956.x

54. Soria-Mercado IE, Prieto-Davo A, Jensen PR, Fenical W (2005) Antibiotic terpenoid chlorodihydroquinones from a new marine actinomycete. J Nat Prod 68(6):904-910. https://doi.org/10.1021/np058011z

55. Jeong SY, Shin HJ, Kim TS, Lee HS, Park SK, Kim HM (2006) Streptokordin a new cytotoxic compound of the methylpyridine class from a marine derived Streptomyces sp. KORDI-3238. J Antibiot 59(4):234-240. https://doi. org/10.1038/ja.2006.33

56. Sahu MK, Swarnakumar NS, Sivakumar K, Thangaradjou T, Kannan L (2008) Probiotics in aquaculture: importance and future perspectives. Indian J Microbiol 48(3):299-308. https://doi.org/10.1007/s12088-008-0024-3

57. Sheldon PJ, Mao Y, He M, Sherman DH (1999) Mitomycin resistance in Streptomyces lavendulae includes a novel drug-binding-protein-dependent export system. J Bacteriol 181(8):2507-2512. https://doi.org/10.1128/JB.181. 8.2507-2512.1999

58. Mao Y, Varoglu M, Sherman DH (1999) Molecular characterization and analysis of the biosynthetic gene cluster for the antitumor antibiotic mitomycin C from Streptomyces lavendulae NRRL 2564. Chem Biol 6(4):251263. https://doi.org/10.1016/S1074-5521(99)80040-4

59. Chiu HT, Hubbard BK, Shah AN, Eide J, Fredenburg RA, Walsh CT, Khosla C (2001) Molecular cloning and sequence analysis of the complestatin biosynthetic gene cluster. Proc Natl Acad Sci 98(15):8548-8553. https://doi. org/10.1073/pnas.151246498

60. Angelova L, Dalgalarrondo M, Minkov I, Danova S, Kirilov N, Serkedjieva J, Chobert JM, Haertlé T, Ivanova I (2006) Purification and characterization of a protease inhibitor from Streptomyces chromofuscus 34-1 with an antiviral activity. Biochim Biophys Acta 1760(8):1210-1216. https://doi.org/10.1016/j. bbagen.2006.03.002

61. Wei Y, Fang W, Wan Z, Wang K, Yang Q, Cai X, Shi L, Yang Z (2014) Antiviral effects against EV71 of pimprinine and its derivatives isolated from Streptomyces sp. Virol J 11(1):195-209. https://doi.org/10.1186/s12985-014-01 95-y

62. Bhawsar S (2011) Microbial production of vitamin B12. Biotechnol Prod (3):5-21

63. Thompson CJ, Fink D, Nguyen LD (2002) Principles of microbial alchemy: insights from the Streptomyces coelicolor genome sequence. Genome Biol 3(7):1020.1-1020.4. https://doi.org/10.1186/gb-2002-3-7-reviews1020

64. Wawrik B, Kutliev D, Abdivasievna UA, Kukor JJ, Zylstra GJ, Kerkhof L (2007) Biogeography of actinomycete communities and type II polyketide synthase genes in soils collected in New Jersey and Central Asia. Appl Environ Microbiol 73(9):2982-29894. https://doi.org/10.1128/aem.02611-06

65. Amal AM, Abeer KA, Samia HM, Nadia AH, Ahmed KA, El-Hennawi HM (2011) Selection of pigment (melanin) production in Streptomyces and their application in printing and dyeing of wool fabrics. Res J Chem Sci 1(5):22-28

66. Sathi ZS, Sugimoto N, Khalil MI, Gafur MA (2002) Isolation of yellowish antibiotic pigment 4-hydroxy nitrobenzene from a strain of Streptomyces. Pak J Biol Sci 52(2):201-203. https://doi.org/10.3923/pjbs.2002.201.203

67. Moore BS, Trischman JA, Seng D, Kho D, Jensen PR, Fenical W (1999) Salinamides, antiinflammatory depsipeptides from a marine streptomycete. J Organomet Chem 64(4):1145-1150. https://doi.org/10.1021/jo9814391

68. Morens DM, Folkers GK, Fauci AS (2004) The challenge of emerging and reemerging infectious diseases. Nature 430(6996):242-249. https://doi.org/10.1 038/nature02759

69. Kundu S, Sahu MK, Sivakumar K, Kannan L (2006) Occurrence of antagonistically active extra-cellular enzyme producing actinomycetes in the alimentary canal of estuarine fishes. Asian J Microbiol Biotech Envi Sci 8: 707-710

70. Sahu MK, Sivakumar K, Poorani E, Thangaradjou T, Kannan L (2007) Studies on L-asparaginase enzyme of actinomycetes isolated from esturine fishes. J Environ Biol 28(2):465-474
71. Vignardet C, Guillaume YC, Friedrich J, Millet J (1999) A first order experimental design to assess soluble proteins released by a new keratinase from Doratomyces microsporus on human substrates. Int J Pharm 191(2):95102. https://doi.org/10.1016/S0378-5173(99)00283-5

72. Prakash D, Nawani N, Prakash M, Bodas M, Mandal A, Khetmalas M, Kapadnis B (2017) Actinomycetes: a repertory of green catalysts with a potential revenue resource. BioMed Res Inter:1-8. https://doi.org/10.1155/2 $013 / 264020$

73. Stutzenberger FJ (1987) Inducible thermoalkalophilic polygalacturonate lyase from Thermornonospora fusca. J Bacteriol 169(6):2774-2780. https://doi. org/10.1128/jb.169.6.2774-2780.1987

74. Bode W, Huber R (1992) Natural protein proteinase inhibitors and their interaction with proteinases. Eur J Biochem 204(2):433-451. https://doi.org/1 0.1111/j.1432-1033.1992.tb16654.x

75. Sun Z, Lu W, Liu P, Wang H, Huang Y, Zhao Y (2015) Isolation and characterization of a proteinaceous a-amylase inhibitor AAI-CC5 from Streptomyces sp. CC5, and its gene cloning and expression. Antonie Van Leeuwenhoek 107(2):345-356. https://doi.org/10.1007/s10482-014-0333-y

76. Weibel EK, Hadvary P, Hochuli E, Kupfer E, Lengsfeld H (1987) Lipstatin, an inhibitor of pancreatic lipase, produced by Streptomyces toxytricini. I. Producing organism, fermentation, isolation and biological activity. J Antibiot 40(8):1081-1085. https://doi.org/10.7164/antibiotics.40.1081

77. Manivasagana P, Venkatesan J, Sivakumar K, Kim S (2014) Pharmaceutically active secondary metabolites of marine actinobacteria. Microbiol Res 169(40):262-278. https://doi.org/10.1016/j.micres.2013.07.014

78. Jayaprakashvel M (2012) Therapeutically active biomolecules from marine actinomycetes. J mod Biotechnol 1(1):1-7

79. Barbie P, Kazmaier U (2016) Total synthesis of cyclomarin a, a marine cycloheptapeptide with anti-tuberculosis and anti-malaria activity. Org Lett 18(2):204-207. https://doi.org/10.1021/acs.orglett.5b03292

80. Imade C, Okami Y (1995) Characteristics of marine actinomycete isolated from a deep-sea sediment and production of beta-glucosidase inhibitor J Mar Biotechnol 2:109-113

81. Raja S (2007) Screening of microbial amylase enzyme inhibitors from marine actinomycetes. M.Sc., dissertation. Annamalai University, India, p 40

82. Nakamura H, litaka Y, Kitahara T, Okazaki T, Okami Y (1977) Structure of aplasmomycin. J Antibio 30(9):714-719. https://doi.org/10.7164/antibiotics.3 0.714

83. Fiechter A (1992) Biosurfactants: moving towards industrial application. Trends Food Sci Technol 3:286-293. https://doi.org/10.1016/S0924-2244 (10)80013-5

84. Feller G, Le Bussy O, Gerday C (1998) Expression of psychrophilic genes in mesophilic hosts: assessment of the folding state of a recombinant aamylase. Appl Environ Microbiol 64(3):1163-1165. https://doi.org/10.1128/A EM.64.3.1163-1165.1998

85. Thampayak I, Cheeptham N, Wasu P, Pimporn L, Saisamorn L (2008) Isolation and identification of biosurfactant producing actinomycetes from soil. Res J Microbiol 3(7):499-507. https://doi.org/10.3923/jm.2008.499.507

86. Chakraborty S, Ghosh M, Chakraborti S, Jana S, Sen KK, Kokare C, Zhang L (2015) Biosurfactant produced from Actinomycetes nocardiopsis A17: characterization and its biological evaluation. Int J Biol Macromol 79:405412. https://doi.org/10.1016/j.ijbiomac.2015.04.068

\section{Publisher's Note}

Springer Nature remains neutral with regard to jurisdictional claims in published maps and institutional affiliations. 